measures. Infect Control Hosp Epidemiol 1992;13:725-737.

24. Ribner BS, Landry MN. Gholson GL. Strict versus modified isolation for prevention of nosocomial transmission of methicillin-resistant Staphylococccus aureus. Infect Control 1986:7:317-320.

25. Guiguet M, Rekacewicz C, Leclercq B, Brun Y, Escudier B, Andermont A. Effectiveness of simple measures to control an outbreak of nosocomial methicillin-resistant Staphylococcus aureus infections in an intensive care unit. Infect Control Hosp Epidemiol 1990;11:23-26.

26. Cohen SH, Morita MM, Bradford M. A seven year experience with methicillin-resistant Staphylococcus aureus. Am J Med 1991;31 (suppl 3B): $233 \mathrm{~S}-237 \mathrm{~S}$.

27. Strausbaugh LJ, Jacobson C, Yost T. Methicillin-resistant Staphylococcus aureus in a nursing home and affiliated hospital: a four-year perspective. Infect Control Hosp Epidemiol 1993;14:331-336.

28. Lynch P Jackson MM, Cummings MJ, Stamm WE. Rethinking the role of isolation practices in the prevention of nosocomial infections. Ann Intern Med 1987;107:243-246.

29. Rimland D, Roherson B. Gastrointestinal carriage of methicillin-resistant Staphylococcus aureus. J Clin Microbiol 1986;24:137-138.

30. Walsh TJ. Vlahov D, Hansen SL, et al. Prospective microbiologic surveillance in control of nosocomial methicillin-resistant Staphylococcus aureus. Infect Control 1987;87:7-14.

31. Rao N, Jacobs S, Joyce L. Cost-effective eradication of an outbreak of methicillin-resistant Staphylococcus aureus in a community teaching hospital. Infect Control Hosp Epidemiol 1988;9:255260.

32. Department of Health and Human Services, Centers for Disease Control and Prevention. Draft guideline for isolation precautions in hospitals. Federal Register 1994;59(214):55552-55570.

33. Mulligan ME, Murray-Leisure KA, Ribner BS. et al. Methicillin-resistant Staphylococcus aureus: a consensus review of the microbiology, pathogenesis, and epidemiology with implications for prevention and management. Am J Med 1993;94:313-328.

34. Boyce JM, Jackson MM, Pugliese G, et al. Methicillin-resistant Staphylo- coccus aureus (MRSA): a briefing for acute care hospitals and nursing facilities. Infect Control Hosp Epidemiol 1994:15:105113.

35 Maslow JN, Mulligan ME, Arbeit RD. Molecular epidemiology: application of contemporary techniques to the typing of microorganisms. Clin Infect Dis 1993;17:153-164.

36 Klein BS, Perloff WH, Maki DG. Reduction of nosocomial infection during pediatric intensive care by protective isolation. $N$ Engl ] Med 1989;320:17141721.

37 Stamm AM, Long MN, Belcher B. Prospective, randomized trial of barrier isolation versus universal precautions during medical intensive care (letter). Am J Infect Control 1993;21:163.

38. Weinstein RA. Epidemiology and control of nosocomial infections in adult intensive care units. Am J Med 1991:91 (suppl 3B) :179S-184S.

39. Chetchotisakd P, Phelps CL, Hartstein AL Assessment of bacterial cross-transmission as a cause of infections in patients in intensive care units. Clin Infect Dis 1994;18:929-937.

40. Pfaller MA. Microbiology: the role of the clinical laboratory in hospital epidemiology and infection control. In: Wenzel RP, ed. Prevention and Control of Nosocomial Infections. 2nd ed. Baltimore, MD: Williams and Wilkins; 1993:385-405.

41. Goering RV. Molecular epidemiology of nosocomial infection: analysis of chromosomal restriction fragment patterns by pulsed-field gel electrophoresis. Infect Control Hosp Epidemiol 1993;14:595-600.

42. Pfaller MA. The use of molecular techniques for epidemiologic typing of Candido species. Curr Top Med Mycol 1992;4:43-63.

43. Girardin H, Sarfati J, Traore F, Dupouy Camet J, Derouin F, Latge JP. Molecular epidemiology of nosocomial invasive aspergillosis. $J$ Clin Microbiol 1994;32:684-690.

44. Peterson LR, Petzel RA, Clabots CR, Fasching CE, Gerding DN. Medical technologists using molecular epidemiology as part of the infection control team. Diagn Microbiol Infect Dis 1993;16:303-311.

\title{
CDC Reports a Decline in TB Cases for Second Year in a Row
}

\section{by Gina Pugliese, RN, MS Medical News Editor}

The CDC recently reported that there were 24,361 new US tuberculosis (TB) cases in 1994, a $3.7 \%$ decrease from 1993's 25,287 cases. This decline is the second in a row, $8.7 \%$ below 1992, and partially reverses the $20 \%$ increase in cases that occurred from 1985 through 1992. Dr. Kenneth Castro, director of CDC's division of tuberculosis elimination, reported these figures at the American Thoracic Society's annual meeting in Seattle, Washington. CDC's director, Dr. David Satcher, said, "This is a public health success made possible by increased federal funding of approximately $\$ 100$ million over 2 years, as well as state and local TB control efforts."

Experts report that the resurgence in TB in the United States has been related to funding cutbacks in the 1980 s, the HIV epidemic, increased immigration from countries in which
TB is endemic, and increases in the homeless and prison populations. It is estimated that 10 to 15 million people in the United States have latent TB infection. Worldwide, TB is the leading cause of adult death from an infectious disease.

FROM: CDC reports 24,361 cases of TB, a decline from 1992. Press release; May 23, 1995: Centers for Disease Control and Prevention, Atlanta, Georgia. 